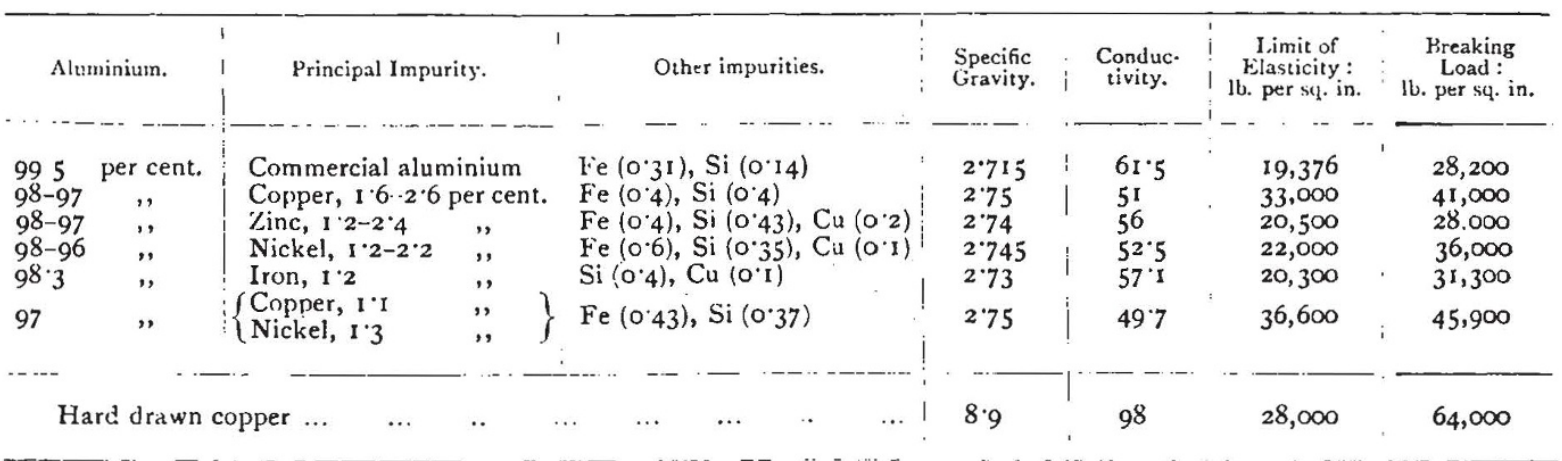

and strength of this alloy enabling spans of I 50 feet to be made with safety. A great saving in the number of poles is thus effected, which is one of the principal advantages gained. Numerous other important transmission schemes might be quoted in which aluminium is used, or in which it has been decided to use it. As has been just pointed out, the use of aluminium effects a great saving in the number of poles required; it also involves dealing with a much smaller weight of conductor, and is, finally, cheaper than copper. In round numbers, for equal conductivity, the section of an aluminium cable is one and a half times that of a copper one, the weight is half and the tensile strength three-quarters. It is the decreased weight which, in spite of the smaller tensile strength, allows longer spans to be used, and this effect can be made more marked by the use of a suitable alloy possessing increased strength without much diminished conductivity or much higher specific gravity. Mr. Morrison gives an interesting table showing the variation, according to the price of copper, in the price per lb. that can be paid for aluminium for equal conductivity and equal cost. From this it appears that with copper at its present price of about tenpence per Ib., twenty-one pence per lb. could be paid for aluminium, which is two or three pence above its market price, showing that aluminium conductors are cheaper.

It is to be noted that the above remarks apply only to bare conductors. Where insulated cables are needed for low-tension work the increased diameter of an aluminium conductor involves increased cost in insulating material ; moreover, with lead-covered cables the increased weight of the lead would almost, if not quite, cancel the decrease in weight gained by substituting aluminium for copper. For high-tension cables it is possible that aluminium may in some cases be cheaper than copper. Thus in a paper by Mr. M. O'Gorman ${ }^{1}$ it is shown that increasing the diameter of the conductor may produce such a diminution in the depth of insulation necessary as to lessen the total price ; in such circumstances a tubular copper conductor, or an aluminium conductor, could be used with advantage. There seems, therefore, a possibility that aluminium may some day successfully invade the field of insulated cables, hitherto regarded as pecu. liarly the property of copper.

M. S.

\section{RECENT WORKS ON SYSTEMATIC BOTANY IN GERMANY.}

I T was in the year $\mathrm{I} 887$ that, following on the publisher's announcement, the first parts of "Die natürlichen Pflanzenfamilien" appeared under the joint editorship of Drs. Engler and Prantl. The announcement does not seem to have attracted much attention, as there was no mention of it in many botanical journals until several numbers following each other rapidly came under notice. Strange as it may seem, De Bary's name does not appear as one of the collaborators, nor did he have any share in

1 "Insulation on Cables," by Mervyn O'Gorman. (Journal of the Institution of Electrical Engineers, vol. xxv. p. 608.$)$

No. I 222 , vOL. 66$]$ the work. His remarks, therefore, as set forth in Die Botanische Zeitung in October, 1887 , besides providing a criticism of the general scheme, also enable one to form an idea of the attitude displayed towards the undertaking.

He says, "the object is to present by means of illustrations and descriptions a corporate picture of the plant world which shall be strictly scientific and at the same time generally intelligible. Under each family, and for each genus of that family, mention will be made of any. points that call for description or that have a practical bearing."

That there was some uncertainty as to its successful completion may be gathered from what he says later, after congratulating editor and publisher:-

"If the book is only carried through as it has been started, then it will have no equal ... since it gives in. formation shortly and objectively, not in the abstruse and learned manner of Bentham and Hooker, nor yet in the form of the subjectively learned monograph touched up with popular varnish which characterises the otherwise life-like history of plants by Baillon." Undoubtedly the terse and vigorous descriptions, the careful choice of matter, and the wealth of illustration which elicited favourable comment for the earlier numbers have, on the whole, been consistently maintained. Now that the work is almost completed, and as one looks back on the enormous labour entailed, congratulations may again be offered to Dr. Engler, who has been the sole editor since Dr. Prantl died in 1893 .

The responsibility of such a vast undertaking might well be sufficient, but in the year $1900 \mathrm{Dr}$. Fngler announced the publication of a new work, "Das Pflanzen. reich"-adopting the title suggested by De Bary-which will amplify the information given in "Die naturlichen Pflanzenfamilien." As Dr. Engler announces in his introduction, "Das Pflanzenreich" is not a revised edition of "Die natürlichen Pflanzenfamilien," for appendices to the latter will continue to appear fron time to time, and whereas "Die Pflanzenfamilien" gives a complete account of the orders and genera, but only enumerates a few species, "Das Pflanzenreich" will furnish a full and comparative account of all authenticated species.

Eleven parts have already been issued --" Musacex," by K. Schumann ; "Typhacex and Sparganiacea," by P. Graebner; "Pandanaceæ," by O. Warburg; "Monimiaceæ," by J. Perkins and E. Gilg ; "Rafflesiaceæ and Hydnoracex," by H. Graf zu Solms Laubach ; "Symplocace:e," by A. Brand ; "Naiadacex," by A. B. Rendle ; "Aceraceæ," by F. Pax ; "Myrsinaceic," by C. Mez; "Tropxolacex," by Fr. Buchenau ; and "Marantaceæ," by K. Schumann.

As regards the general arrangement, the citation of important literature and the review of the main characters of the order are similar to the method adopted in "Die Pflanzenfamilien," and, together with a certain number of illustrations, will be more or less the same. 13ut, apart from new facts which may be added, it will be observed that the orders are not necessarily taken up by the same authors in the two works. English botanists may be 
allowed to express their satisfaction with the inclusion of one of our ablest systematic workers.

The key and description for each species are given in Latin, in order that, as the author remarks, they may be available to the botanists of all nations. The parts will not be issued in any particular sequence, the only proviso being that no order will be forthcoming until at least twelve years have elapsed since it was treated either in "Die Pflanzenfamilien" or in De Candolle's "Suites au Prodromus." Each part dealing with one order will be complete in itself and will contain an index.

Apart from the memoirs incorporated in these two works, many of the studies in systematic botany, the results of which have been published in Germany within recent years, have been controlled more or less by Dr. Engler in his position as director of the Botanical Museum in Berlin. The "Flora of Africa," which has reached the twenty-third instalment, represents mainly the investigations of workers in the Berlin Museum. One of the assistants, Dr. L. J)iels, has written an able memoir on the "Flora von Central China." It is especially noticeable how distant and comparatively unknown are many of the countries in which the herbaria have been formed which are finding their way to the museums in Germany. The same spirit of unflagging energy which has made famous the names of many German collectors, whose object has been to acquire fame by sending home flowers previously unknown, may here be found, but the incentive is merely scientific enthusiasm.

\section{NOTES.}

THe Huxley Memorial Tablet represented in the accompanying illustration was unveiled at the Ealing Public Library on Thursday last by the Mayor of Ealing, Alderman H. C. Green. The inscription upon the tablet is, "The Right Honourable Thomas Henry Huxley. Born at Ealing, 4th May, 1825. Died at Eastbourne, 29th June, I895. Try to learn something about

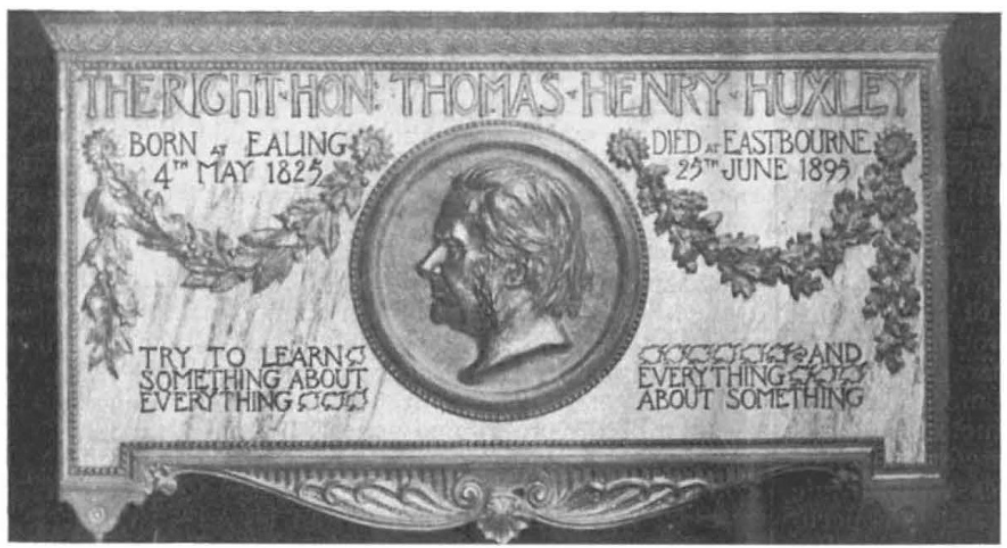

Huxley, Mr. and Mrs. Leonard Huxley, Mr. L. Fletcher, F.R.S., Mr. B. B. Woodward, and Mr. F. E. Beddard, F.R.S. (representing the Zoological Society of London). Letters regretting inability to attend were read from Prof. Howes and Lord George Hamilton. Prof. Henslow gave a short address, in the course of which he related some personal reminiscences of Huxley; and the Mayor of Ealing afterwards unveiled the tablet. The accompanying photograph having been taken before the tablet was erected, an error of the mason's, undetected at the time, but since corrected, gives the date of Huxley's death as the $25^{\text {th }}$ instead of the 29 th of June, 1895.

WE regret to see the announcement of the death of the Rev. Dr. Wiltshire, formerly professor of geology and mineralogy at King's College, London.

THE opening meeting of the Institution of Electrical Engineers is fixed for Thursday, November 13 , when the premiums awarded for papers read or published during the session I90I-I902 will be presented, and the president, Mr. James Swinburne, will deliver his inaugural address.

A t the recent conference of Colonial Premiers, a resolution in favour of the metric system of weights and measures was adopted. Referring to this action, Mr. Chamberlain has informed a correspondent that he fully recognises the importance of the matter, and is in correspondence with the Colonial Governments and the Board of Trade on the subject.

In reply to a question in the House of Commons on Thursday last, Mr. Austen Chamberlain said :-A new cable has been laid to Belgium, and telephonic communication between London and Brussels will be opened as soon as the necessary arrangements can be completed. The establishment of communication between London and Berlin is not at present feasible.

ENERGETIC measures are being adopted at Odessa to prevent the spread of plague from the cases which have occurred there. The outbreak of the disease in May of this year is attributed to the presence of rats, which have carried the means of infection since the last case of plague was treated in Odessa in November, rgor. Systematic efforts are therefore being made to destroy the colonies of rats and carry out strict sanitary regulations.

THE chief members or the Scottish Antarctic Expedition about to start for the South Polar regions were entertained to dinner in Edinburgh on Thursday last by the president of the Royal Scottish Geographical Society, Sir John Murray. Replying to the toast proposing success to the expedition, Mr. W. S. Bruce, the leader, remarked that the work undertaken would be supplementary to that of the three expeditions already in the Antarctic,

everything, and everything about something." The whole memorial was designed by Mr. Frank Bowcher, with the assistance of Prof. G. B. Howes, F.R.S. The background of the tablet is "Dove" marble; the frame, top row of lettering, wreaths and medallion are bronze; the rest of the inscription is in incised gilt letters. The movement to establish this memorial originated with Mr. B. B. Woodward, who brought it before the Ealing Natural Science Society, and a committee was formed with him as hon. secretary. Altogether about eighty subscriptions were received, mainly from Ealing residents, hence the tablet shows that the memory of Huxley is cherished at his birthplace. Among those present at Thursday's ceremony, in addition to the Mayor, were Prof. G. Henslow, Mrs. T. H. No. 1722 , vOL. 66] and would be largely oceanographical. The Scottish area of activity would be around that part of the Antarctic where Sir James Ross, sixty years ago, took one sounding, attaining a depth of 4000 fathoms without reaching bottom.

THE Home Secretary has appointed a committee to inquire into the use of electricity in mines and the dangers attending it, and to report what measures should be adopted in the interests of safety by the establishment of special rules or otherwise. The committee consists of Mr. H. H. S. Cunynghame, C.B. (chairman), Mr. Charles Fenwick, M.P., Mr. Archibald Hood, past president of the Mining Association of Great Britain, Mr. James Swinburne, president of the Institution of Electrical 